\title{
A Note About Dr. John Virgo
}

\author{
Alan Hochstein
}

Published online: 29 June 2013

(C) International Atlantic Economic Society 2013

It is with sadness that I heard about the untimely passing of Dr. John Virgo. Though I am writing this note with a heavy heart, at the same time, I am pleased to have this opportunity to talk a little bit about how John and the International Atlantic Economic Society (henceforth IAES) have influenced my academic career.

I have been employed by Concordia Universty in Montréal since 1985, and I am a full professor in the Finance Department. In 2011, I concluded my term as Dean of the Faculty of Business at the John Molson School of Business at Concordia and returned to the faculty as a simple professor doing what I love to do most, my teaching and research. Although I have been academically successful on many measures and I have enjoyed my entire time at the University, my happiest days were when I first joined the business school about 28 years ago. At that time, I was a young, enthusiastic, naïve, wide eyed academic starting out as a faculty member at a major world class university. Everything was new, stimulating, and exciting.

My first application for a conference presentation was to an International Atlantic Economic Conference. I cannot explain the feeling of elation on reading the note from John that my paper had been accepted for presentation. There is something about being accepted by ones peers that transcends other positive rewards, and I recall that feeling even as I am writing these words. It was my first conference paper presentation and it was in Rome, Italy.

When I arrived at the hotel, I made it a special point to look for John and introduce myself to him. I felt the urge to explain that it was my first conference. He was always around and easy to find. It was John's way to be understanding, helpful, kind, and considerate, to be interested in my work, to be involved with the participants, and to simply be an excellent host. He made me feel comfortable, and this was not easy to do for a new presenter.

At later IAES conferences, I searched for John to talk about my major interest in economics at that time- health economics. As was his way, he showed more than a

\footnotetext{
A. Hochstein $(\bowtie)$

Department of Finance, John Molson School of Business, Concordia University, Montréal, Canada e-mail: ahoch@jmsb.concordia.ca
} 
passing interest in my work and explained that he was as involved with my topic as I was. Again, his interest was so very satisfying to me. I made sure to give him my business card and looked forward to our next meeting.

After my fifth year at the business school, when all went well with my department, I went out of my way to meet John again at an IAES conference to explain that his attitude towards me, the IAES conferences, and its journals were all instrumental in my achieving tenure. I am convinced of this. Too often we forget or sometimes ignore the ones who had important influences on our careers. I won't do this.

John, I think of you often. 